\title{
Prevalence of overweight and underweight in schoolchildren in Constantine, Algeria: comparison of four reference cut-off points for body mass index
}

\author{
Hayet Oulamara, ${ }^{1}$ Ouassila Allam, ${ }^{1}$ Fouzia Tebbani ${ }^{1}$ and Abdel-Nacer Agli ${ }^{1}$
}

${ }^{1}$ Laboratoire de Nutrition et Technologie Alimentaire, Institut National de l'Alimentation, la Nutrition et des Technologies Agro-Alimentaires, Université des Frêres Mentouri Constantine, Constantine, Algeria. (Correspondence to: Hayet Oulamara: houlamara@gmail.com).

\begin{abstract}
Background: Algeria is experiencing a nutritional transition and increasing overweight in children.

Aims: This study aimed to determine the prevalence of overweight and underweight in children aged 6-10 years in Constantine city, Algeria using four international reference cut-offs for body mass index.

Methods: A cross-sectional study was conducted between February and May 2015 with a sample of 509 schoolchildren aged 6-10 years. Height and weight were measured according to World Health Organization (WHO) recommendations. The body mass index cut-offs of WHO, International Obesity Task Force, Centers for Disease Control and Prevention (CDC) and French national references were used to classify the sample as underweight and overweight according to age and sex. The kappa coefficient was used to assess agreement between the reference cut-offs.

Results: Based on the of different reference cut-offs, the prevalence of underweight in the children varied from $1.4 \%$ to $8.8 \%$. The prevalence of overweight varied from $22.8 \%$ to $28.3 \%$. The WHO cut-off gave a significantly higher prevalence of overweight in boys than girls (32.6\% versus $24.0 \%, P=0.03$ ). The kappa values (between 0.251 and 0.954 ) indicated a fair to excellent agreement between the different reference cut-offs.

Conclusion: The prevalence of overweight and underweight differs in the Constantine children depending on the reference cut-off used, suggesting international references should be used with care to avoid potential misclassification of children's nutritional status.

Keywords: child, body mass index, nutritional status, overweight, underweight, Algeria

Citation: Oulamara H; Allam O; Tebbani F; Agli A. Prevalence of overweight and underweight in schoolchildren in Constantine, Algeria: comparison of four reference cut-off points for body mass index. East Mediterr Health J. 2020;26(3):349-355. https://doi.org/10.26719/2020.26.3.349

Received: 23/02/17; accepted: 25/07/18

Copyright (c) World Health Organization (WHO) 2020. Open Access. Some rights reserved. This work is available under the CC BY-NC-SA 3.0 IGO license (https://creativecommons.org/licenses/by-nc-sa/3.o/igo).
\end{abstract}

\section{Introduction}

Overweight is increasing in children worldwide while underweight is decreasing in many countries. Among children in developing countries, underweight is still a greater problem than overweight. However, many countries have experienced a rising trend in the prevalence of overweight children $(1,2)$. This shift is attributed to marked changes in lifestyles including increased sedentary behaviour and the introduction of westernized poor-quality diets and drinks. This nutritional transition is underway, at varying rates, in most developing countries, including Algeria.

In Algeria, we do not have representative nationwide studies on the prevalence of overweight and obesechildren older than 5 years. Local studies conducted in some regions do not allow defining the nationwide prevalence. However, they raise awareness that overweight and obesity in children in Algeria is increasing and could become a real public health problem. In Constantine, based on a sample of 19263 children aged 6-10 years, the prevalence of overweight including obesity increased from $6.8 \%$ in 2001 to $9.5 \%$ in 2006 and the prevalence of underweight decreased from $34.3 \%$ to $24.5 \%$ (3).
Body mass index (BMI) is used extensively to measure malnutrition. Various international BMI reference cut-offs are available to determine the prevalence of malnutrition, particularly overweight and underweight in children. These include reference cut-off points of the International Obesity Task Force (IOTF) (4), the United States Centers for Disease Control and Prevention (CDC 2000) (5), French reference cut-off points published in 1982 and revised in 1991 (6), and the World Health Organisation (WHO), 2007 (7) and IOTF-2007 (8).

Our study aimed to determine the prevalence of overweight including obesity and underweight in a sample of children aged 6-10 years living in Constantine city using different international reference cut-off points for BMI to allow comparison between different studies and countries.

\section{Methods}

\section{Study setting}

The study was conducted in the city of Constantine, which is the capital of the province of Constantine (in the north-east of Algeria). Constantine is located $439 \mathrm{~km}$ 
from Algiers, the capital of Algeria. It is the third largest city of Algeria in terms of population. In the last census of 2008 (9), the resident population of the city of Constantine was 448374 . The population of children aged 6-10 years was 32937 .

\section{Study sample}

This cross-sectional study was conducted between February and May 2015, and covered a sample of 509 children (254 girls and 255 boys) aged 6-10 years attending primary schools in the city of Constantine. Four schools were selected. These schools were chosen for their location in different geographical areas of Constantine. We could not assess other schools as we did not have permission from the Primary Education Department of Constantine to include more schools. In Algeria, school education is free and obligatory, so children of all social categories are present. All children aged 6-10 years attending these four schools were chosen.

\section{BMI criteria}

Height and weight were measured according to WHO recommendations (10) by a trained student. The body weight (in kilograms) was measured to the nearest 0.1 $\mathrm{kg}$ using regularly calibrated electronic scales (Seca, Germany). Height was measured in a standing position without shoes to the nearest $0.1 \mathrm{~cm}$ using a stadiometer (Seca, Germany). BMI was calculated as weight (kg) divided by height squared $\left(\mathrm{m}^{2}\right)$. The $2007 \mathrm{WHO}$ reference cut-off is based on the sample used to construct the original charts of the American Department of Health, Education and Welfare (11). The 2007 WHO reference allows unrestricted calculation of BMI centiles and Z-score curves on a continuous age scale from 5 to 19 years. A score of $>1$ standard deviation (SD) is considered the overweight cut-off point, a score of $<-2$ SD is considered the underweight cut-off point (7). The IOTF reference has published a series of sex- and age-specific BMI cut-offs (from 6 to 18 years) which were developed from sex-specific BMI age curves that pass through a BMI of $25 \mathrm{~kg} / \mathrm{m} 2$ for overweight and $30 \mathrm{~kg} / \mathrm{m} 2$ for obesity at age 18 years (4). For the detection of underweight, IOTF constructed reference cut-offs based on the WHO definition of underweight for adults (8). The CDC 2000 reference is the revised version of the 1977 (American) National Center for Health Statistics growth charts. Here, the 85th centile is considered the cut-off for overweight and the 5 th centile the cut-off for underweight (5). According to the French reference published in 1982 and revised in 1991, underweight and overweight are defined as < 3rd centile and > 97th centile respectively (6).

\section{Statistical analysis}

Statistical analysis was done using Statview software, version 5 (Abacus ConceptsTM, Berkeley, USA). Data were analysed using the chi-squared and Student t-tests to assess differences by age and sex. The kappa coefficient was used to assess the inter-variation between the references. A kappa value > 0.4 was considered moderate agreement, and a value $>0.75$ was considered good agreement (12). The significance level was set at $P<0.05$.

\section{Results}

The mean BMI of the children according to age and sex increased with age between 6 and 10 years with no statistically significant difference by sex (Table 1).

Table 2 shows the prevalence of underweight and overweight by age of the children. The four reference cut-offs all indicated a low prevalence of underweight. The IOTF cut-off showed the highest prevalence of underweight in all age. The new reference cut-off of WHO showed no underweight in children younger than 8 years. For overweight, the French reference indicated a comparatively low prevalence of overweight compared with the other reference cut-offs. The WHO reference showed the highest prevalence of overweight in all ages.

The prevalence of underweight and overweight by age and sex according to various references are presented in Table 3. The overall prevalence of overweight as determined by IOTF and French cut-offs followed a similar trend in both sexes. IOTF and French references classified $21.3 \%$ and $18.9 \%$ of the girls and $24.3 \%$ and $22.0 \%$ of the boys, respectively, as overweight. The WHO reference showed a significantly higher prevalence of overweight in boys than girls $(32.6 \%$ versus $24.0 \%, P=$ 0.03). This was because $39.6 \%$ of 7 -year-old boys were classified as overweight with the WHO reference cutoff compared with $18.8 \%$ of 7 -year-old girls $(P=0.01)$ as were $43.2 \%$ of 10year-old boys compared with $22.6 \%$ of 10-year-old girls $(P=0.03)$. The prevalence of overweight according to the $\mathrm{CDC}$ reference cut-offs was much higher in boys compared with girls, even though overall the difference was not statistically significant $(26.3 \%$ versus $19.3 \%, P=0.06)$. However, the CDC reference cut-offs showed a significantly higher prevalence of overweight in 7-year-old boys than in girls (37.5\% versus $17.4 \%$ respectively, $\mathrm{P}=0.01)$. The IOTF reference shows the highest prevalence of underweight for girls (10.6\%) and boys (7.1\%).

The kappa coefficients comparing overweight and underweight between the different reference cut-offs are presented in Table 4. With regard of the detection of underweight, the kappa coefficient values (boys $=0.89$, girls $=0.95$ ) suggest an excellent agreement between

\begin{tabular}{|c|c|c|c|}
\hline \multirow[t]{2}{*}{ Age (years) } & \multicolumn{2}{|c|}{ Mean body mass index (SD) } & \multirow[t]{2}{*}{ P-value } \\
\hline & Girls & Boys & \\
\hline 6 & $23.47(3.44)$ & $24.28(4.80)$ & 0.33 \\
\hline 7 & $25.75(5.15)$ & $27.41(5.55)$ & 0.09 \\
\hline 8 & $31.46(9.37)$ & $29.58(6.73)$ & 0.24 \\
\hline 9 & $32.66(7.58)$ & $33.94(8.57)$ & 0.47 \\
\hline 10 & 36.38 (8.99) & $38.98(9.04)$ & 0.16 \\
\hline
\end{tabular}




\begin{tabular}{|c|c|c|c|c|c|c|}
\hline \multirow[t]{2}{*}{ Variable } & \multicolumn{6}{|c|}{ Prevalence (\%) } \\
\hline & 6 years $(n=111)$ & 7 years $(n=117)$ & 8 years $(n=101)$ & 9 years $(n=83)$ & 10 years $(n=97)$ & Total $(n=509)$ \\
\hline \multicolumn{7}{|l|}{ Underweight } \\
\hline WHO & 0.0 & 0.0 & 2.0 & 2.4 & 3.1 & 1.4 \\
\hline IOTF & 9.0 & 11.1 & 4.9 & 8.4 & 10.3 & 8.8 \\
\hline $\mathrm{CDC}$ & 2.7 & 2.6 & 3.0 & 2.4 & 6.2 & 3.3 \\
\hline French reference & 1.8 & 1.7 & 2.0 & 2.4 & 3.1 & 2.2 \\
\hline \multicolumn{7}{|l|}{ Overweight } \\
\hline WHO & 28.8 & 27.3 & 27.7 & $25 \cdot 3$ & 31.9 & 28.3 \\
\hline IOTF & 23.4 & 22.2 & 23.8 & 20.5 & 23.7 & 22.8 \\
\hline $\mathrm{CDC}$ & 23.4 & 25.6 & 22.8 & 19.3 & 21.6 & 22.8 \\
\hline French reference & 20.7 & 17.9 & 19.8 & 20.5 & 23.7 & 20.4 \\
\hline
\end{tabular}

WHO: World Health Organization, IOTF: International Obesity Task Force, CDC: Centers for Disease Control and Prevention.

WHO and French references for both sexes (kappa = 0.77). An excellent agreement was also found between the French and CDC references (boys, kappa $=0.91$ and girls, kappa $=0.93)$. However, the kappa values show very low agreement for boys between IOTF and WHO reference cut-offs (kappa $=0.35)$, IOTF and CDC $(\mathrm{kappa}=0.48)$ and IOTF and French $(\mathrm{kappa}=0.42)$.

In terms of overweight, in girls, an excellent agreement between all references was found (kappa between 0.76 and 0.94). For boys, an excellent agreement was found between WHO and CDC references (kappa $=$ $0.85)$ and between IOTF and CDC (kappa $=0.95)$ and IOTF and French references (kappa $=0.93)$.

\section{Discussion}

In our sample, the prevalence of underweight using different reference cut-offs varied from $1.4 \%$ to $8.8 \%$.
This prevalence is lower than that observed in India (13) and Morocco (14) but close to that found in Algeria (Sidi-bel-Abbes) in 2008 (15).

Few studies have reported the prevalence of obesity, which has reached epidemic proportions among children in developing countries $(16,17)$. Using the CDC and IOTF reference cut-offs, $22.8 \%$ of our sample of children were overweight. This prevalence is considerably lower than that found in Saudi Arabia (40.6\%) (18), Libya (45\%) (19), Abu Dhabi (33.6\%) (20), Egypt (31.2\%) (21) and South Africa (30.7\%) (22). However, it is higher than that found in the Islamic Republic of Iran (19.7\%) (23), India (13.2\%) (24), and Turkey (13.3\%) (25). It is similar to the prevalence found in Jordan (24.4\%) (26). Using the WHO reference cutoffs we found a prevalence of overweight of $28.3 \%$. This prevalence is higher than that in Yemen (20.7\%) (27) and Nigeria (13\%) (28) but close to that in Saudi Arabia (28.7\%) (29) and lower than that in Dubai (40.9\%) (30).

\begin{tabular}{|c|c|c|c|c|c|c|c|c|c|c|c|c|c|}
\hline \multirow[t]{3}{*}{ Variable } & \multicolumn{12}{|c|}{ Prevalence (\%) } & \multirow{3}{*}{$\begin{array}{c}P- \\
\text { value }\end{array}$} \\
\hline & \multicolumn{6}{|c|}{ Girls } & \multicolumn{6}{|c|}{ Boys } & \\
\hline & $\begin{array}{l}6 \text { years } \\
(n=46)\end{array}$ & $\begin{array}{l}7 \text { years } \\
(n=69)\end{array}$ & $\begin{array}{l}8 \text { years } \\
(n=44)\end{array}$ & $\begin{array}{l}9 \text { years } \\
(n=42)\end{array}$ & $\begin{array}{c}10 \text { years } \\
(n=53)\end{array}$ & $\begin{array}{c}\text { Total } \\
(n=254)\end{array}$ & $\begin{array}{l}6 \text { years } \\
(n=65)\end{array}$ & $\begin{array}{l}7 \text { years } \\
(n=48)\end{array}$ & $\begin{array}{l}8 \text { years } \\
(n=57)\end{array}$ & $\begin{array}{l}9 \text { years } \\
(n=41)\end{array}$ & $\begin{array}{l}10 \text { years } \\
(n=44)\end{array}$ & $\begin{array}{c}\text { Total } \\
(n=255)\end{array}$ & \\
\hline \multicolumn{14}{|l|}{ Underweight } \\
\hline WHO & 0.0 & 0.0 & 0.0 & 2.4 & 3.8 & 1.1 & 0.0 & 0.0 & 3.5 & 2.4 & 2.3 & 1.6 & 0.71 \\
\hline IOTF & 8.7 & 13.0 & 4.5 & 9.5 & 15.1 & 10.6 & 9.2 & 8.3 & $5 \cdot 3$ & $7 \cdot 3$ & 4.5 & 7.1 & 0.15 \\
\hline $\mathrm{CDC}$ & 4.3 & 2.9 & 2.3 & 2.4 & 9.4 & 4.3 & 1.5 & 2.1 & 3.5 & 2.4 & 2.3 & 2.4 & 0.21 \\
\hline $\begin{array}{l}\text { French } \\
\text { reference }\end{array}$ & 4.4 & 1.5 & 0.0 & 2.4 & 3.8 & 2.4 & 0.0 & 2.1 & 3.5 & 2.4 & 2.3 & 2.0 & 0.75 \\
\hline \multicolumn{14}{|l|}{ Overweight } \\
\hline WHO & 23.9 & $18.8^{*}$ & 34.1 & 23.8 & $22.6^{*}$ & $24.0^{*}$ & 32.3 & 39.6 & 22.8 & 26.8 & 43.2 & 32.6 & 0.03 \\
\hline IOTF & 21.7 & 18.8 & 29.5 & 19.0 & 18.9 & 21.3 & 24.6 & 27.1 & 19.3 & 21.9 & 29.5 & 24.3 & 0.41 \\
\hline $\mathrm{CDC}$ & 21.7 & $17.4^{*}$ & 27.3 & 16.7 & 15.1 & 19.3 & 24.6 & 37.5 & 19.3 & 21.9 & 29.5 & 26.3 & 0.06 \\
\hline $\begin{array}{l}\text { French } \\
\text { reference }\end{array}$ & 17.4 & 14.5 & 27.3 & 19.1 & 18.9 & 18.9 & 23.1 & 22.9 & 14.0 & 21.9 & 29.5 & 22.0 & 0.39 \\
\hline
\end{tabular}

WHO: World Health Organization, IOTF: International Obesity Task Force, CDC: Centers for Disease Control and Prevention.

${ }^{*}$ Significant at $P<0.05$. 
Table 4 Agreement of different reference cut-offs in classifying underweight, overweight and obesity in a sample of Algerian children in Constantine

\begin{tabular}{|c|c|c|c|c|c|c|c|c|}
\hline \multirow[t]{3}{*}{ Variable } & \multicolumn{8}{|c|}{ Kappa coefficient } \\
\hline & \multicolumn{3}{|c|}{ Underweight } & \multicolumn{3}{|l|}{ Overweight } & \multicolumn{2}{|c|}{ Obesity $^{a}$} \\
\hline & IOTF & CDC & $\begin{array}{l}\text { French } \\
\text { reference }\end{array}$ & IOTF & CDC & $\begin{array}{l}\text { French } \\
\text { reference }\end{array}$ & IOTF & CDC \\
\hline \multicolumn{9}{|c|}{ Boys (6-10 years combined) } \\
\hline WHO & 0.347 & 0.796 & 0.887 & 0.799 & 0.850 & 0.737 & 0.715 & 0.934 \\
\hline IOTF & & 0.482 & 0.417 & & 0.948 & 0.934 & & 0.736 \\
\hline $\mathrm{CDC}$ & & & 0.907 & & & 0.882 & & \\
\hline \multicolumn{9}{|c|}{ Girls (6-10 years combined) } \\
\hline WHO & 0.711 & 0.884 & 0.954 & 0.900 & 0.840 & 0.828 & 0.760 & 0.917 \\
\hline IOTF & & 0.819 & 0.753 & & 0.940 & 0.928 & & 0.734 \\
\hline $\mathrm{CDC}$ & & & 0.930 & & & 0.912 & & \\
\hline \multicolumn{9}{|c|}{ Total children (6-10 years combined) } \\
\hline WHO & 0.251 & 0.575 & 0.774 & 0.846 & 0.846 & 0.778 & 0.733 & 0.928 \\
\hline IOTF & & 0.525 & 0.371 & & 0.944 & 0.930 & & 0.737 \\
\hline $\mathrm{CDC}$ & & & 0.780 & & & 0.896 & & \\
\hline
\end{tabular}

IOTF: International Obesity Task Force, CDC: Centers for Disease Control and Prevention, WHO: World Health Organization.

${ }^{a}$ There is no cut-off for obesity in French reference.

In Algeria, representative nationwide studies on the prevalence of overweight and obese children are not yet available. Using IOTF reference, in Constantine, the prevalence of overweight in children 6-10 years was 9.5\% in 2006 (3). In Tébessa (eastern Algeria), between 2005 and 2007, the reported prevalence was 8.5\% (31). In Oran city (western Algeria), 13\% of children aged 6-11 years were overweight (32), while, in Sidi-bel-Abbes (also western Algeria), in 2008, the prevalence of overweight using IOTF, French and CDC references in 8-15-yearold children was respectively $7.9 \%, 7.7 \%$ and $7.2 \%$ (15). In Constantine, using WHO reference cut-offs, the prevalence of overweight in 7-11-year-old children in 2013 was reported to be $26.4 \%$ (33).

The higher prevalence of overweight in our study might be explained by the recent trend of socio-economic transition coupled with the nutrition transition in Algeria. This prevalence of overweight is a challenge for public health interventions because overweight children are at a higher risk of noncommunicable and degenerative diseases in adulthood. It is not only the availability of and household access to food that determines the nutritional status of children. Factors such as education, sanitation, accessibility and quality of health services, and cultural attitudes and beliefs are equally important. In the area of Constantine, we showed in 2003 that watching television, time spent in sedentary activities and food quality were risk factors for overweight in a sample of schoolchildren aged 6 to 12 years (34). In the current sample, we also collected information on risk factors for overweight and found that overweight children did less sport, ate breakfast less often, and watched 2 hours more television than normal weight children (35). We also observed a link between parental and child obesity, and that the prevalence of overweight was more common in children who were not exclusively breastfed whose mothers worked.

The differences in the prevalence of underweight and overweight using the different references can be explained by the setting different cut-offs used by the references, which can be influenced by factors such as time period, country of data source and design of the study. Thus, it is advisable to know the basis on which a reference cut-off was calculated before applying it to any population-based study.

\section{Conclusion}

The considerable prevalence of overweight and a persistent burden of underweight found in our sample suggests the existence of nutrition transition in Constantine. The prevalence of malnutrition differs depending on the reference used, which suggests international references should be used with care to avoid any potential misclassification of children. The differences obtained by using different cut-off points at the individual and population level need further research to answer questions as to whether certain cut-off points are linked or not with morbidity or mortality endpoints. No Algerian national standard or reference is available to define overweight or underweight in Algerian children. It may be that Algerian children have different growth characteristics from the populations that were selected to develop the international references. Thus local age-specific BMI references and cut-offs for children are needed that can provide accurate predictions of the risk of metabolic morbidity and disease burden throughout life.

\section{Funding: None}

Competing interests: None declared. 


\section{Prévalence du surpoids et du déficit pondéral chez les écoliers de Constantine (Algérie) : comparaison de quatre valeurs de référence utilisées comme seuils pour l'indice de masse corporelle}

\section{Résumé}

Contexte : L'Algérie connaît une période de transition nutritionnelle et une augmentation un surpoids chez l'enfant.

Objectifs : La présente étude visait à déterminer la prévalence du surpoids et du déficit pondéral chez les enfants âgés de 6 à 10 ans à Constantine (Algérie), au moyen de quatre valeurs internationales de référence utilisées comme seuils pour l'indice de masse corporelle (IMC).

Méthodes : Une étude transversale a été réalisée entre février et mai 2015 dans un échantillon de 509 écoliers âgés de 6 à 10 ans. Leur taille et leur poids ont été mesurés selon les recommandations de l'Organisation mondiale de la Santé (OMS). Les valeurs utilisées comme seuils pour l'IMC par l'OMS, le groupe spécial international sur l'obésité, les Centers for Disease Control and Prevention (CDC) et les valeurs de référence nationales françaises ont été employées pour classer l'échantillon selon les catégories «surpoids » et « déficit pondéral » en fonction de l'âge et du sexe. Le coefficient kappa a été utilisé pour évaluer la concordance entre les valeurs de référence.

Résultats : Sur la base des différentes valeurs de référence utilisées comme seuils, la prévalence du déficit pondéral chez les enfants était comprise entre $1,4 \%$ et $8,8 \%$. La prévalence du surpoids variait de $22,8 \%$ à $28,3 \%$. La valeur de référence utilisée comme seuil par l'OMS donnait une prévalence du surpoids considérablement plus élevée chez les garçons que chez les filles $(32,55 \%$ contre $24,0 \%, p=0,03)$. Les valeurs du coefficient kappa (entre 0,251 et 0,954) indiquaient une correspondance allant de bonne à excellente entre les références.

Conclusion : La prévalence du surpoids et du déficit pondéral diffère chez les enfants de Constantine selon la valeur de référence utilisée comme seuil, ce qui semble indiquer que les valeurs internationales de référence devraient être utilisées avec prudence afin d'éviter toute erreur de classification de l'état nutritionnel des enfants.

$$
\begin{aligned}
& \text { انتشار زيادة الوزن ونقص الوزن لدى طلاب المدارس في قسنطينة، الجز ائر : مقارنة أربع نقاط فاصلة مرجعية لمنسب كتلة } \\
& \text { حياة اولعمارة، وسيلة علام، فوزية تباني، عبد الناصر عقلي } \\
& \text { الخلفية: تشهد الجزائر تحو لاً في أساليب التغذية وزيادةً في الوزن بصورة متنامية بين الأطفال. } \\
& \text { الأهداف: هدفت الدراسة إلى تحديد زيادة الوزن ونقص الوزن لدى الأطفال الذين تتراوح أعلارهم ما بين ج- • 1 سنوات فئ في قسنطينة، الجزائر، وذلك }
\end{aligned}
$$

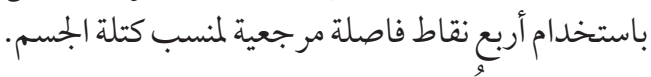

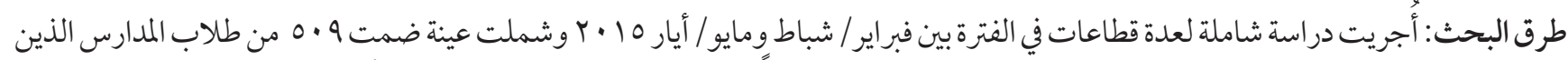

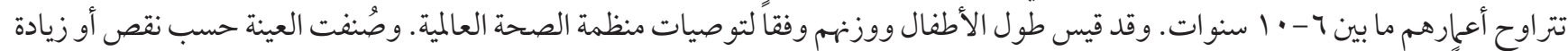

\section{References}

1. De Onis M, Blossner M. The World Health Organization (WHO) global database on child growth and malnutrition: methodology and application. Int J Epidemiol. 2003;32:518-26. http://doi.org/10.1093/ije/dygo99

2. WHO Global Database on Child Growth and Malnutrition. Geneva: World Health Organization (https://www.who.int/nutgrowthdb/en/, accessed 6 December 2019). 
3. Oulamara H, Agli AN, Frelut ML. Changes in the prevalence of overweight, obesity and thinness in Algerian children between 2001 and 2006. Int J Pediatr Obes. 2009;4:411-13. http://doi.org/10.3109/17477160802596163

4. Cole TJ, Bellizi MC, Flegal KM, Dietz WH. Establishing a standard definition for child overweight and obesity worldwide: international survey. BMJ. 2000; 320:1-6. http://doi.org/10.1136/bmj.320.7244.1240

5. Kuczmarski RJ, Ogden CL, Grummer-Strawn LM, Flegal KM, Guo SS, Wei R, et al. CDC growth charts: United States. Adv Data. 2000;314:1-27.

6. Rolland-Cachera MF, Cole TJ, Sempe M, Tichet J, Rossignol C, Charraud A. Body mass variations: centile from birth to 87 years. Eur J Clin Nutr. 1991;45:13-21.

7. De Onis M, Onyango AW, Borghi E, Siyam A, Nishida C, Siekmann J. Development of a WHO growth reference for school-aged children and adolescents. Bull World Health Organ. 2007;85:660-7. http://doi.org/10.2471/blt.07.043497

8. Cole TJ, Flegal KM, Nicholls D, Jackson AA. Body mass index cut offs to define thinness in children and adolescents: international survey. BMJ. 2007;335:194-201. http://doi.org/10.1136/bmj.39238.399444.55

9. Algeria population and housing census 2008. Algiers: National Office of Statistics; 2011:220 (Statistics Collections, No. 163/2011, Series S).

10. Obesity: preventing and managing the global epidemic. Report of a WHO Consultation. Geneva: World Health Organization; 1995 (WHO Technical Report Series, No. 894).

11. NCHS growth curves for children, birth-18 years, United States. Hyattsville (MD): Department of Health, Education and Welfare; 1977 .

12. Landis JR, Koch GG. The measurement of observer agreement for categorical data. Biometrics, 1977;33:159-74.

13. Sikdar M. Prevalence of malnutrition among the missing children of northeast India: a comparison between four different sets of criteria. N Am J Med Sci. 2012;4:305-9. http://doi.org/10.4103/1947-2714.98589.

14. Sbaibi R, Aboussaleh Y. Etude exploratoire de l'état staturo-pondéral des enfants collégiens dans la commune rurale Sidi El Kamel au Nord-Ouest Marocain [Exploratory study of the height and weight status of schoolchildren in the rural community of Sidi El Kamel, north-western Morocco]. Antropo. 2011;24:61-6.

15. Diaf M, Meghit Khaled B. Prevalence of overweight and obesity in 8 to 15 year-old children in Sidi-bel-Abbes, Algeria. S Afr J Sports Med. 2011;2(10):10-5. 10.5742/mejfm.2011.910114

16. Popkin BM, Doak CM. The obesity epidemic is a worldwide phenomenon. Nutr Rev. 1998;56(4):106-14. http://doi. org/10.1111/j.1753-4887.1998.tbo1722.x

17. Martorell R, Kettel Khan L, Hugues ML, Grummer-Strawn LM. Overweight and obesity in preschool children from developing countries Int J Obes Relat Metab Disord. 2000;24:959-67. http://doi.org/10.1038/sj.ijo.0801264

18. Al Saleh A. Prevalences of overweight and obesity among Saudi children. Int J Sci Res. 2015;4(9):765-9.

19. Elabani FA, Kure J. Study the prevalence of overweight and obesity among Libyan children in relation to their socioeconomic level status and fast food meals. Libyan J Med Res. 2015;9(2):4-14.

20. Al Junaibi A, Abdulle A, Sabri S, Hag-Ali M, Nagelkerke N. The prevalence and potencial determinants of obesity among school children and adolescents in Abu Dhabi, United Arab Emirates. Int J Obes. 2013;37:68-74. http://doi.org/10.1038/ijo.2012.131

21. El-Said Badawi N, Abo Barakat A, Awad El Sherbini S, Mohamed Fawzy H. Prevalence of overweight and obesity in primary school children in Port Said city. Gaz Egypt Paediatr Assoc. 2013;61:31-6.

22. 22 Mc Kersie J, Baard ML. Obesity in 7-10-year-old children in urban primary schools in Port Elizabeth. S Afr J Sports Med. 2014;24(2):55-8.

23. Karimi B, Ghorbani R. Overweight and obesity in the Iranian schoolchildren. Middle East J Rehabil Health, $2015 ; 2(1): e 24433$. http://doi.org/10.17795/mejrh-24433

24. Kalpana CA, Lakshmi UK. Prevalence of overweight and obesity among school children in Coimbatore city, Tamilnadu. Int J Curr Res. 2011;3(8):12-6.

25. Ari Yuca S, Yilmaz C, Cesur Y, Dogan M, Kaya A, Basaranoglu M. Prevalence of overweight and obesity in children and adolescents in Eastern Turkey. J Clin Res Pediatr Endocrinol. 2010;2(4):159-63. http://doi.org/10.4274/jcrpe.v2i4.159

26. Abu Baker NN, Daradkeh SM. Prevalence of overweight and obesity among adolescents in Irbid governorate, Jordan. East Mediterr Health J. 2010;16(6):657-62.

27. Badi MAH, Garcia Triana BE, Suarez Martinez R. Overweight/obesity and socioeconomic status in children from Aden governorate, Yemen, 2009. Rev Habanera Cienc Med. 2013;12(3):364-73.

28. Opara DC, Ikpeme EE, Ekanem US. Prevalence of stunting, underweight and obesity in school aged children in Uyo, Nigeria. Pakistan J Nutr. 2010;9 (5):459-66. http://doi.org/10.3923/pjn.2010.459.466

29. Al-Enazy WH, Al-Enazy FS, Al-Enazy FA, Al-Qahtani MA. Prevalence of overweight and obesity among Saudi primary school students in Tabuk, Saudi Arabia. Int J Med Sci Public Health. 2014;3(8):993-9. http://doi.org/10.5455/ijmsph.2014.080620141

30. Bin Zaal AA, Brebner J, Musaiger AO, Souza D. Anthropometric characteristics and obesity among adolescents in the United Arab Emirates. East Mediterr Health J. 2011;17(5):382-6. 
31. Taleb S, Oulamara H, Agli A. Change in the prevalence of overweight and obesity among school children in Tebessa (eastern Algeria) between 1995 and 2007. J Obes Weight Loss Ther. 2012;2:109.

32. Raiah M, Talhi R, Mesli MF. Surpoids et obésité des enfants de six à onze ans: prévalence et facteurs associés à Oran [Overweight and obesity in children aged 6-11 years: prevalence and associated factors in Oran]. Santé Publique. 2012;24(6):561-71.

33. Sayed A, Daoudi H, Rouabah A, Khan NA, Rouabah L. Dietary patterns among overweight/obese school children of district of Constantine (Algeria) : a longitudinal study. Int J Sci Res. 2014;3(8):1975-9.

34. Oulamara H, Agli AN, Frelut ML. Alimentation, activité physique et surpoids chez des enfants de l'Est Algérien [Food, physical activity and overweight among children in eastern Algeria]. Cah Nutr Diét. 2006;41(1):46-54.

35. Allam O, Oulamara H, Agli AN. Prévalence et facteurs de risque du surpoids chez des enfants scolarisés dans une ville de l'est algérien (Constantine) [Prevalence and risk factors of overweight in schoolchildren in a city in eastern Algeria (Constantine)]. Antropo. 2016;35:91-102. 